Article

\title{
The Effect of Conditioning on the Flotation of Pyrrhotite in the Presence of Chlorite
}

\author{
Yanfei Chen ${ }^{1}$, Qing Shi ${ }^{1, *}$, Qiming Feng ${ }^{1}$, Yiping $\mathrm{Lu}^{1}$ and Wencai Zhang ${ }^{2}$ \\ 1 School of Minerals Processing and Bioengineering, Central South University, Changsha 410083, China; \\ yanfeichen@csu.edu.cn (Y.C.); qmfeng@126.com.cn (Q.F.); feng_309@csu.edu.cn (Y.L.) \\ 2 Department of Mining Engineering, University of Kentucky, Lexington, KY 40506, USA; wzh257@g.uky.edu \\ * Correspondence: shiqok@csu.edu.cn; Tel.: +86-731-8883-0913
}

Received: 29 May 2017; Accepted: 15 July 2017; Published: 20 July 2017

\begin{abstract}
The influence of conditioning on the flotation of pyrrhotite in the presence of chlorite was investigated through flotation tests, sedimentation tests, and X-ray photoelectron spectroscopy (XPS) analysis. The flotation results show that chlorite slimes dramatically impair the flotation of pyrrhotite. Sedimentation and flotation tests reveal that conditioning can effectively remove chlorite slimes from pyrrhotite surfaces, resulting in an enhanced flotation recovery of pyrrhotite. When mixed minerals were conditioned under the natural atmosphere, a faster conditioning speed and longer conditioning time decreased the flotation recovery of pyrrhotite. However, when mixed minerals were conditioned under a nitrogen atmosphere, a more intensive conditioning process provided better flotation results. XPS analyses illustrate that a faster conditioning speed and longer conditioning time under the natural atmosphere accelerates the oxidation of pyrrhotite, leading to a decrease in the flotation recovery of pyrrhotite.
\end{abstract}

Keywords: conditioning; pyrrhotite; chlorite; flotation

\section{Introduction}

Chlorite, as a typical magnesium-rich phyllosilicate mineral, widely exists in many metal sulfide ore deposits [1]. In sulfide flotation, magnesium silicate $(\mathrm{MgO})$ gangue minerals containing chlorite are known to cause problems by adhering to valuable mineral particles in "hetero-aggregation or slime coating" due to the differences in surface charges [2,3]. Coating of chlorite slime particles on sulfide mineral surfaces will decrease the hydrophobicity of the sulfide mineral and may also reduce the collector adsorption, which will result in lower recoveries of the valuable sulfide minerals $[4,5]$.

Pyrrhotite is one of the most abundant sulfide minerals [6]. Furthermore, it is often found in nickel sulfide ores and associated with valuable minerals, which suggests that pyrrhotite losses result in significant losses of nickel minerals [7].

In order to improve the flotation recoveries of the sulfide mineral, the effect of both conditioning speed and conditioning time was observed in the flotation process [8-10]. Zhang et al. achieved better carbon flotation recovery and separation efficiency by increasing the intensity of conditioning [11]. Bulatovic found that conditioning could improve the flotation recovery of copper-nickel sulfide ores and copper-zinc sulfide ores in addition to concentrating the grade [12,13]. Feng et al. studied the effect of high intensity conditioning on the flotation of sulfide and found that high intensity conditioning could significantly increase the flotation recovery of copper-nickel sulfide ores [14]. However, the influence of conditioning on the flotation of pyrrhotite in the presence of chlorite has not been investigated.

In this paper, the influence of conditioning on the flotation of pyrrhotite in the presence of chlorite was studied. Furthermore, the interacting mechanisms were also discussed for providing guidance for further study. 


\section{Materials and Methods}

\subsection{Samples and Reagents}

A chunk of the sample containing unliberated pyrrhotite minerals was obtained from the Tongling mine located in Anhui, China. The collected sample was hammered into small pieces to liberate the pyrrhotite minerals, which were sorted out based on the color differences. X-ray diffraction analyses (Figure 1) of the hand-sorted pyrrhotite concentrates indicated that the sample was of considerably high purity with trace amounts of pyrite. The dry sample was ground in a lab-scale ball mill using ceramic media to eliminate contaminations. The ground sample was screened into different size fractions using sieves with $150 \mu \mathrm{m}$ and $38 \mu \mathrm{m}$ opening sizes. The $-150+38 \mu \mathrm{m}$ size fraction was utilized for the current study.

A chunk of the sample containing unliberated chlorite minerals was also obtained from the Haicheng mine located in Liaoning, China. The collected sample was hammered into small pieces to liberate the chlorite minerals, which were sorted based on the color differences. X-ray diffraction analyses (Figure 2) and elemental analyses (Table 1) of the hand-sorted chlorite concentrate indicated that the sample was of considerably high purity with trace amounts of talc. The dry sample was ground in a lab-scale ball mill using ceramic media to eliminate contaminations. The ground sample was screened into different size fractions using a sieve with $38 \mu \mathrm{m}$ opening size. The $-38 \mu \mathrm{m}$ size fraction was utilized for the current study.

MIBC (methyl isobutyl carbinol) purchased from Tianjin Guangfu Fine Chemical Research Institute, Tianjin, China was used as the frother. $\mathrm{KOH}$ (potassium hydroxide) was used as $\mathrm{pH}$ regulators. All the reagents used in the current study were of analytical grade except for the potassium amyl xanthate (PAX), which was of chemical grade and used as the collector. Deionized double distilled water was used for all tests.

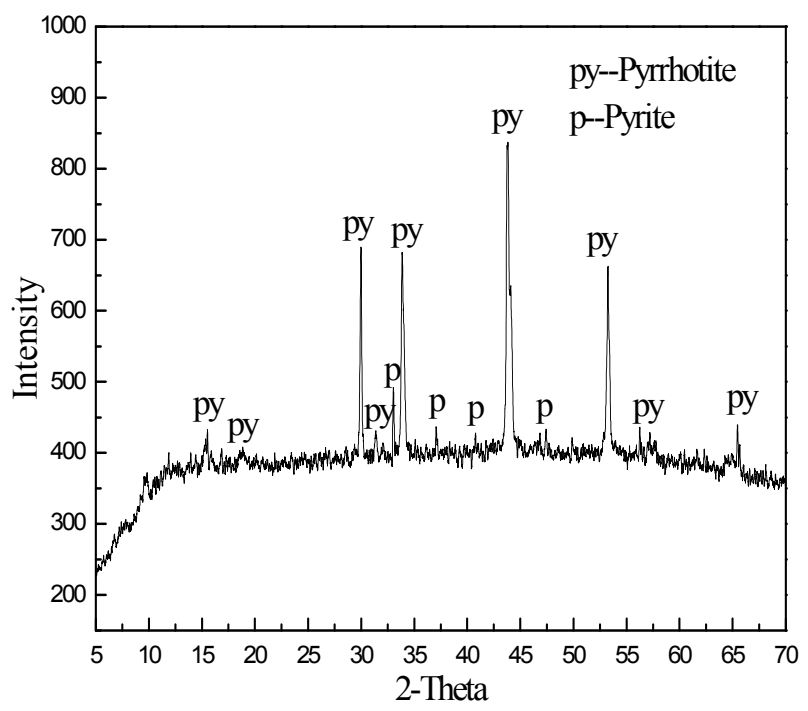

Figure 1. X-ray diffraction (XRD) pattern of the pyrrhotite sample.

Table 1. Chemical compositions of chlorite.

\begin{tabular}{lllcccc}
\hline Composition & $\mathrm{MgO}$ & $\mathrm{SiO}_{2}$ & $\mathrm{Al}_{2} \mathrm{O}_{3}$ & $\mathrm{CaO}$ & $\mathrm{TFe}$ & Other \\
\hline Percentage $/ \%$ & 25.41 & 34.37 & 15.76 & 0.78 & 3.72 & 19.96 \\
\hline
\end{tabular}




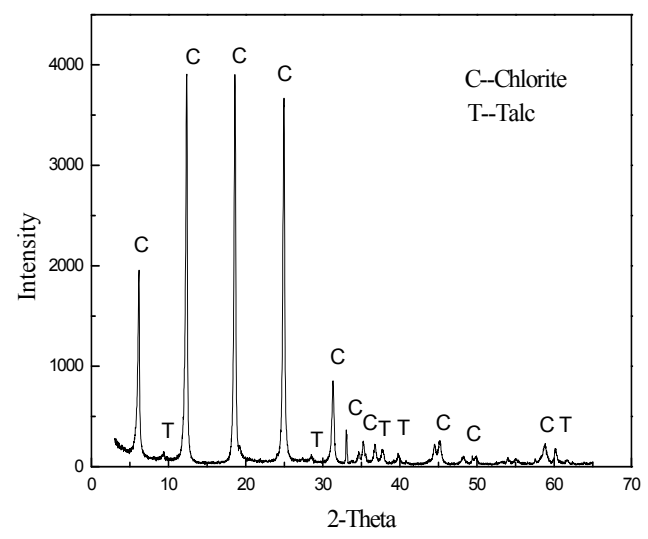

Figure 2. X-ray diffraction (XRD) pattern of the chlorite sample.

\subsection{Experiments}

\subsubsection{Flotation Tests}

Flotation tests were conducted in a XFG type mechanical agitation flotation machine equipped with a flotation cell of $40 \mathrm{~mL}$. For each test, $2.0 \mathrm{~g}$ of minerals was mixed and dispersed in $40 \mathrm{~mL}$ of distilled water in the flotation cell. The slurry was adjusted to a desired value of 9 by adding $\mathrm{KOH}$ solution at a concentration of $1 \times 10^{-5} \mathrm{~mol} / \mathrm{L}$, before this mixture was conditioned for a desired period of time and at a given speed. To test the effects of chlorite on the flotation performance of pyrrhotite, chlorite was added at the beginning of the conditioning process. Control tests were conducted by introducing nitrogen into the pulp throughout the conditioning process to examine the effects of natural atmosphere on pyrrhotite flotation. The prepared PAX (Potassium Amyl Xanthate) solution was added at a desired concentration of $1 \times 10^{-4} \mathrm{~mol} / \mathrm{L}$ and conditioned for $3 \mathrm{~min}$. After that, the agitation speed was adjusted to $1500 \mathrm{rpm}, \mathrm{MIBC}$ was added to the slurry at a desired concentration of $1 \times 10^{-4} \mathrm{~mol} / \mathrm{L}$ and conditioned for $1 \mathrm{~min}$. Following this, flotation was performed at this agitation speed. Each flotation test was performed for $5 \mathrm{~min}$ and five concentrates were collected after cumulative times of 1 , 2, 3, 4, and $5 \mathrm{~min}$. The dry weights of the concentrate and tail were measured and used to calculate the recovery. Each flotation test was measured three times and the average was reported as the final value. The standard deviation, which is presented as an error bar, was obtained using the mean of the three measurements per experimental condition.

\subsubsection{Sedimentation Tests}

Flocculation/dispersion behaviors of the mixed minerals (pyrrhotite/chlorite $=10: 1$ ) in solution were investigated through settling tests, which were conducted in a graduated cylinder. A total of $1 \mathrm{~g}$ of mixed minerals were conditioned in the flotation cell at a desired conditioning speed for $5 \mathrm{~min}$ at a $\mathrm{pH}$ of 9 . Afterwards, the suspension was transferred to a $100-\mathrm{mL}$ cylinder and distilled water was added to bring the water level to $100 \mathrm{~mL}$. The cylinder was stoppered, inverted 20 times, and then set still in an upright position for $3 \mathrm{~min}$. Suspension of the upper $25 \mathrm{~mL}$ of the solution was siphoned out and turbidity of the sample was measured utilizing a WGZ-3(3A) type Scattering Turbidimeter, which is made by the Shanghai Xinrui Instrument Company (Shanghai, China). The degree of flocculation/dispersion was characterized by the turbidity of the supernatant liquor. A lower turbidity value normally indicates a higher degree of flocculation associated with particles in slurries.

\subsubsection{XPS Analysis}

To detect the change in chemical information of the species located on the surface, the pyrrhotite samples were treated at the desired conditioning speed and for the desired period of time. If necessary, nitrogen was introduced into the pulp to protect pyrrhotite from oxidation during conditioning process 
as a contrast. To prevent surface oxidization, the samples were stored in a vacuum drier. The XPS measurements were performed using PHI5000 Versa Probe II (PHI5000, ULVAC-PHI, Chigasaki, Japan). The samples were subjected to a survey scan to first identify chemical components, before high-resolution scans were conducted, focusing on certain elements. The spectra and surface atomic ratios were obtained and calculated based on the XPS PEAK software programmed by Raymond Kwok. Sample charging was compensated by taking the C 1s peak of background hydrocarbon at $284.8 \mathrm{eV}$ as an internal standard.

\section{Results and Discussion}

Since chlorite is of low hardness, the production of slimes may interfere with the flotation of pyrrhotite. Figure 3 shows the flotation recovery of pyrrhotite and grade of sulfur as a function of the amount of chlorite at a $\mathrm{pH}$ of 9 . As shown in Figure 3, the flotation recovery of pyrrhotite in the absence of chlorite is very high (about $85 \%$ ). Upon the addition of chlorite particles, the recovery of pyrrhotite decreases dramatically with an increase in the amount of chlorite particles. When the amount of chlorite reaches $10 \%$ or above, the flotation of pyrrhotite was depressed drastically. Nevertheless, the addition of chlorite makes no difference to the sulfur grade.

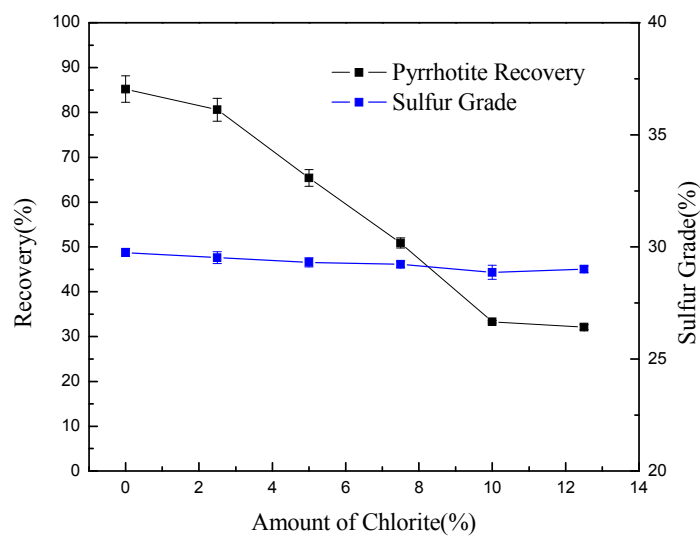

Figure 3. Effect of chlorite on the flotation recovery of pyrrhotite and grade of sulfide $(\mathrm{pH}=9.0 \pm 0.2$; $\mathrm{C}($ potassium amylxanthate $)=1 \times 10^{-4} \mathrm{~mol} / \mathrm{L} ; \mathrm{C}($ methyl isobutyl carbinol $\left.(\mathrm{MIBC}))=1 \times 10^{-4} \mathrm{~mol} / \mathrm{L}\right)$.

To study the effect of chlorite on the depression on pyrrhotite, the XPS measurements of single pyrrhotite and mixed minerals were performed. Both samples were conditioned at a $\mathrm{pH}$ of 9 and a speed of $1500 \mathrm{rpm}$ for $5 \mathrm{~min}$, before being dried in a vacuum drier. For the mixed minerals, we used a magnet to concentrate pyrrhotite, before the solution was rinsed three times with distilled water to remove chlorite by entrainment. Broad-scan XPS results for pyrrhotite and mixed minerals are shown in Figure 4. The two spectra are similar with one major difference. The characteristic peaks for $\mathrm{Mg}$ and $\mathrm{Si}$ are only observed in the spectra $\mathrm{b}$ in Figure 4, which shows that chlorite slimes adhere to the surface of pyrrhotite and restricts the adsorption of xanthate onto the surface of pyrrhotite. Hence, the flotation recovery of pyrrhotite decreases [15].

Conditioning refers to the initial suspension and agitation stage (in preparation for the flotation process) for the finely-ground minerals in water with reagents. It is known that conditioning could desorb slimes from valuable minerals [14]. Thus, to eliminate the adverse effect of chlorite slimes, conditioning was employed. In the process of conditioning, the mineral particles yield fluid force in the flowing pulp. Under these conditions, the sulfide particles and the slime particles have different kinematic velocities due to their different weights and fluid forces. Thus, when the differences in fluid forces imposed on the sulfide and the slime particles exceed the attraction forces between them, the slime particles fall off from the sulfide particles and flowed with the pulp. Therefore, the detachment of chlorite from pyrrhotite surfaces can be realized through conditioning $[9,10]$. The removal of fine 
chlorite particles from pyrrhotite surfaces increases the adsorption density of xanthate and improves its flotation performance $[16,17]$.

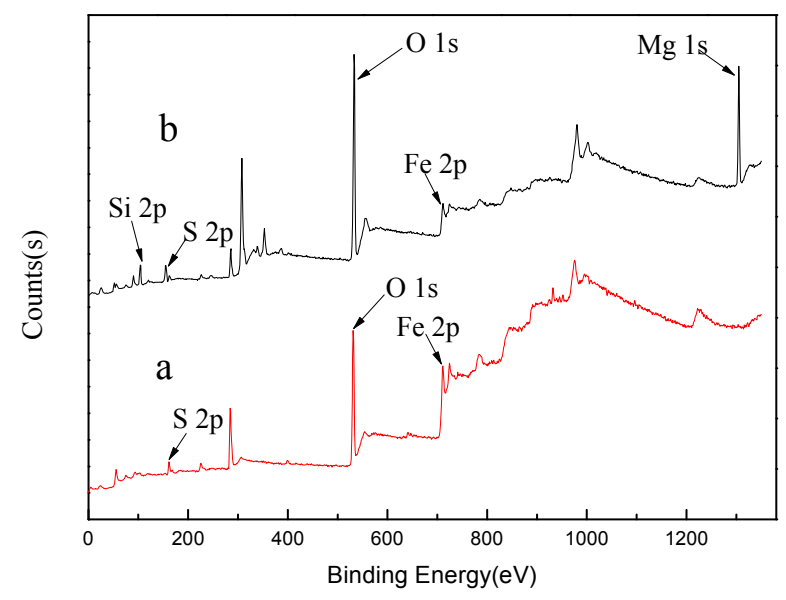

Figure 4. Broad scan X-ray photoelectron spectroscopy (XPS) spectra for: (a) pyrrhotite and (b) mixed minerals (pyrrhotite/chlorite $=10: 1$ ) at a $\mathrm{pH}$ of 9 and a speed of $1500 \mathrm{rpm}$ for $5 \mathrm{~min}$.

Figure 5 shows the effect of conditioning speed and time on the turbidity of pyrrhotite and chlorite slurries. Higher turbidity values indicate a more efficient removal of chlorite slimes from pyrrhotite surfaces. As seen from Figure 5, conditioning can effectively remove chlorite slimes from pyrrhotite surfaces. A faster conditioning speed and longer conditioning time led to higher turbidity values and thus, more efficient chlorite detachment. In order to detect the influence of conditioning on the flotation recovery of pyrrhotite in the presence of chlorite, flotation tests were performed.

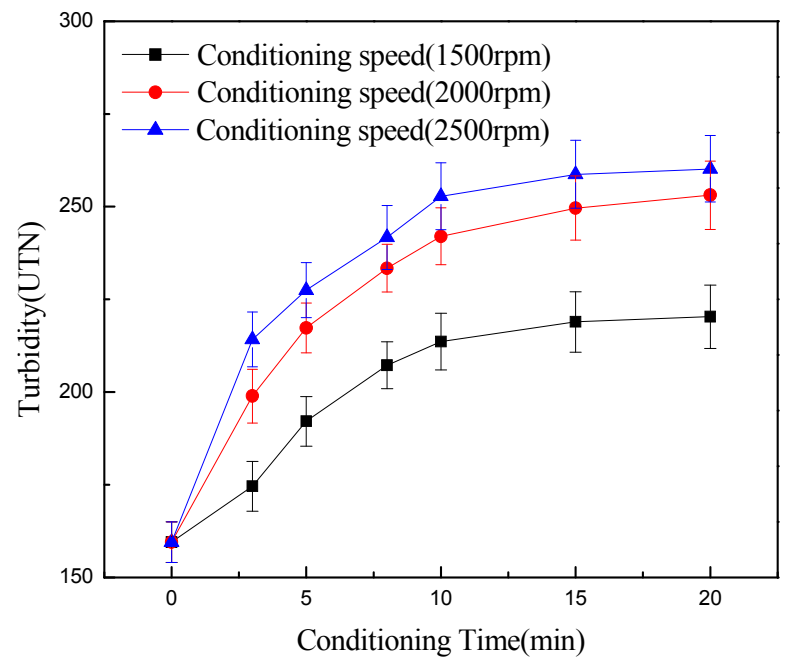

Figure 5. Turbidity of mixed minerals (pyrrhotite and chlorite were mixed by 10:1) as a function of conditioning speed and time of $\mathrm{pH}=9.0 \pm 0.2$.

Figure 6 demonstrates the effect of conditioning speed on the pyrrhotite recovery under the conditioning time of $5 \mathrm{~min}$. The results illustrate that conditioning can dramatically improve the flotation recovery and the best result was obtained with a conditioning speed of $2000 \mathrm{rpm}$. When the conditioning speed was increased up to $2500 \mathrm{rpm}$, the flotation recovery of pyrrhotite decreased.

In addition, in regard to the flotation tests examining the effect of conditioning time on the pyrrhotite recovery under the conditioning speed of $2000 \mathrm{rpm}$, the similar results obtained show that 
the best flotation performance was achieved under the conditioning time of $5 \mathrm{~min}$. Overall, a longer conditioning time decreased flotation recovery (Figure 7).

Previous studies indicated that conditioning increases sulfide mineral flotation recovery significantly, with better flotation performance able to be realized using a longer conditioning time and strong conditioning intensity $[8,14]$. This is not completely consistent with the results shown in Figures 6 and 7.

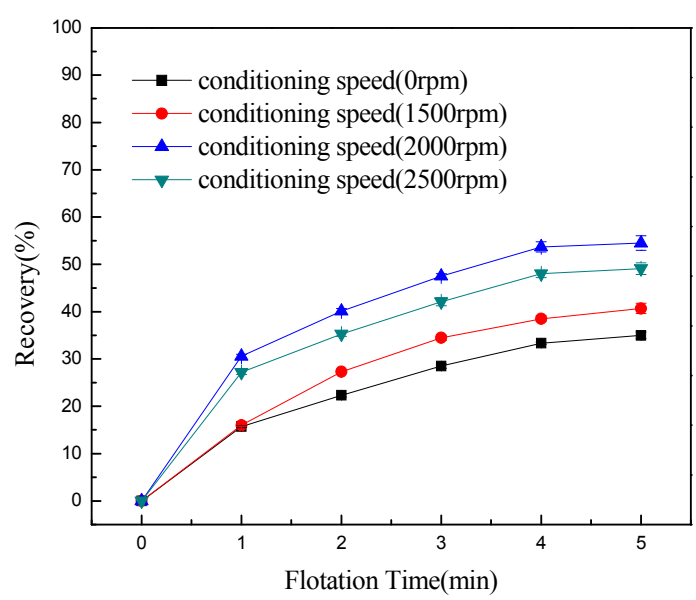

Figure 6. Effect of conditioning speed under natural atmosphere on the recovery of mixed minerals, with pyrrhotite and chlorite mixed at a ratio of 10:1 $(\mathrm{pH}=9.0 \pm 0.2 ; \mathrm{C}$ (potassium amyl xanthate $)=1 \times$ $10^{-4} \mathrm{~mol} / \mathrm{L} ; \mathrm{C}(\mathrm{MIBC})=1 \times 10^{-4} \mathrm{~mol} / \mathrm{L}$; and Conditioning time $\left.=5 \mathrm{~min}\right)$.

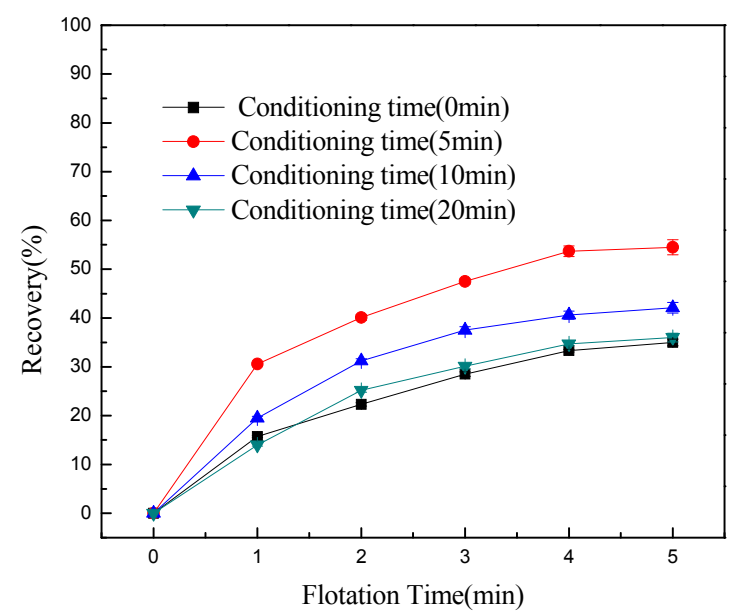

Figure 7. Effect of conditioning time under natural atmosphere on the recovery of mixed minerals, with pyrrhotite and chlorite mixed at a ratio of 10:1 $(\mathrm{pH}=9.0 \pm 0.2 ; \mathrm{C}$ (potassium amyl xanthate $)=1 \times$ $10^{-4} \mathrm{~mol} / \mathrm{L} ; \mathrm{C}(\mathrm{MIBC})=1 \times 10^{-4} \mathrm{~mol} / \mathrm{L}$; and Conditioning time $\left.=5 \mathrm{~min}\right)$.

Pyrrhotite can rapidly react with water and dissolved oxygen in pulp [18]. The rapid oxidation of pyrrhotite will lead to the formation of hydrophilic iron hydroxides, which will coat pyrrhotite surfaces. As such, the adsorption density of xanthate on pyrrhotite surfaces will decrease and the pyrrhotite floatability will be impaired [7,19-22]. This may be the reason why a faster conditioning speed and longer conditioning time decrease the flotation recovery of pyrrhotite.

To get an in-depth understanding of the negative effects of excessive conditioning, a control test was implemented by introducing nitrogen into pulp to remove dissolved oxygen in the process of conditioning. As shown in Figures 8 and 9, a faster conditioning speed and longer conditioning time results in higher flotation recovery of pyrrhotite when the pulp is protected by nitrogen in the 
conditioning process, which is congruent with the sedimentation test results. Furthermore, at the same conditioning speed and for the same period of time, the flotation recovery of pyrrhotite conditioned under the nitrogen atmosphere is higher than that under natural atmosphere. Thus, this reveals that oxygen may interfere with pyrrhotite flotation performance, leading to a decrease in pyrrhotite flotation recovery.

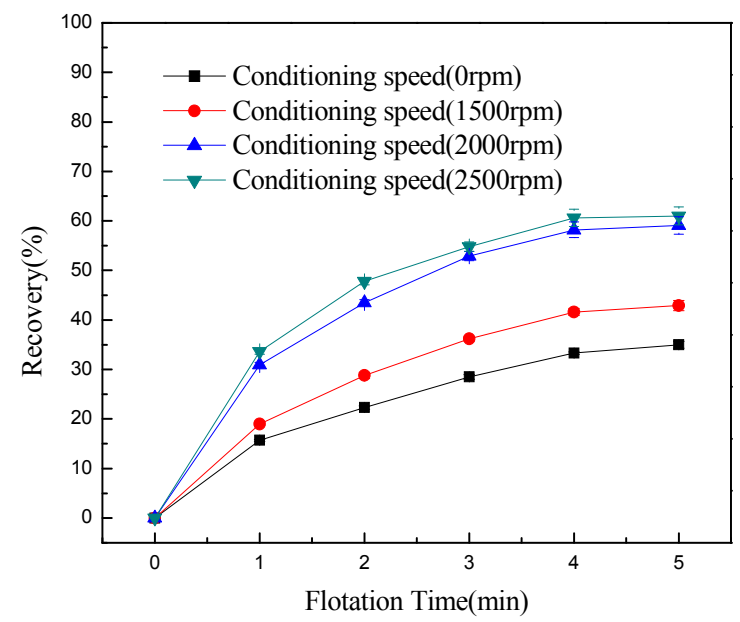

Figure 8. Effect of conditioning speed under nitrogen atmosphere on the recovery of mixed minerals, with pyrrhotite and chlorite mixed at a ratio of $10: 1(\mathrm{pH}=9.0 \pm 0.2 ; \mathrm{C}$ (potassium amyl xanthate $)=1 \times$ $10^{-4} \mathrm{~mol} / \mathrm{L} ; \mathrm{C}(\mathrm{MIBC})=1 \times 10^{-4} \mathrm{~mol} / \mathrm{L}$; and Conditioning time $\left.=5 \mathrm{~min}\right)$.

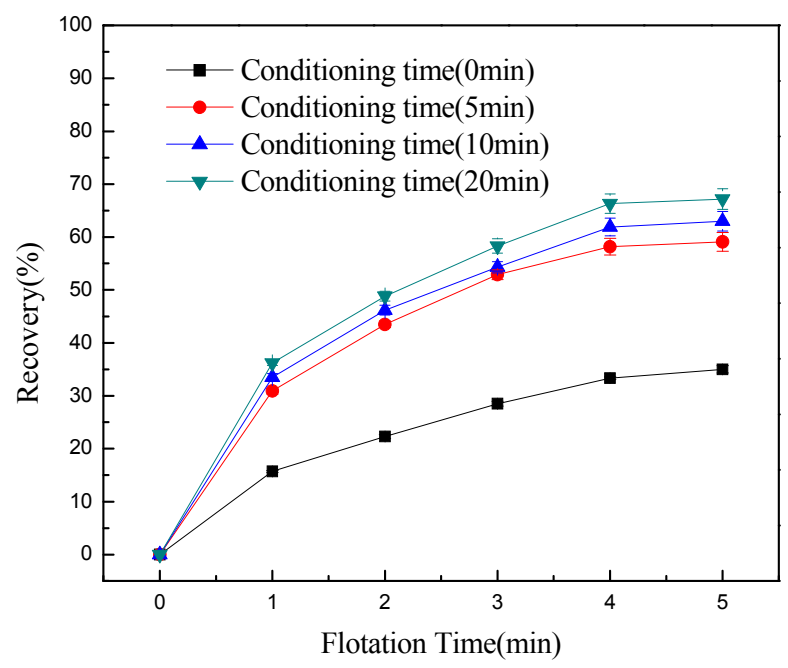

Figure 9. Effect of conditioning time under nitrogen atmosphere on the recovery of mixed minerals, with pyrrhotite and chlorite mixed at a ratio of 10:1 $(\mathrm{pH}=9.0 \pm 0.2 ; \mathrm{C}$ (potassium amyl xanthate $)=1 \times$ $10^{-4} \mathrm{~mol} / \mathrm{L} ; \mathrm{C}(\mathrm{MIBC})=1 \times 10^{-4} \mathrm{~mol} / \mathrm{L}$; and Conditioning time $\left.=5 \mathrm{~min}\right)$.

In order to detect the chemical information of the species on the surface, the pyrrhotite samples treated under different conditions were examined by X-ray photoelectron spectroscopy (XPS). The Fe and $S$ oxidation states on pyrrhotite surfaces were analyzed. The obtained spectra were fitted and the relative contents of different compositions were determined by the XPSPEAK software.

As shown in Figure 10, the Fe2p spectra of pyrrhotite samples treated without conditioning, treated with conditioning under the natural atmosphere for $20 \mathrm{~min}$, and treated with conditioning under nitrogen atmosphere for $20 \mathrm{~min}$ are composed of five peaks at (A) $712.30 \mathrm{eV}$, (B) $711.50 \mathrm{eV}$, (C) $710.60 \mathrm{eV}$, (D) $710.00 \mathrm{e} \mathrm{V}$, and (E) $713.00 \mathrm{eV}$, respectively. By comparing the binding energy values 
of $\mathrm{Fe} 2 \mathrm{p}$ with those from references, the peaks $\mathrm{A}, \mathrm{B}, \mathrm{C}, \mathrm{D}$, and $\mathrm{E}$ are attributed to $\mathrm{Fe}_{2}\left(\mathrm{~S}_{x}\right)_{3}, \mathrm{FeOOH}$, $\mathrm{Fe}_{2} \mathrm{O}_{3}, \mathrm{FeS}$, and $\mathrm{Fe}_{2}\left(\mathrm{SO}_{4}\right)_{3}$, respectively [23-25]. As can be seen from Figure 10 and Table 2, the $\mathrm{Fe}$ species of the untreated pyrrhotite surfaces mainly consist of $\mathrm{Fe}_{2}\left(\mathrm{~S}_{x}\right)_{3}, \mathrm{FeOOH}, \mathrm{Fe}_{2} \mathrm{O}_{3}$, and $\mathrm{FeS}$, the relative contents of which are $45.83 \%, 21.95 \%, 15.78 \%$, and $16.44 \%$, respectively. For the surfaces of the pyrrhotite treated with conditioning under the natural atmosphere for $20 \mathrm{~min}$, the new species of $\mathrm{Fe}_{2}\left(\mathrm{SO}_{4}\right)_{3}$ formed with a relative content of $25.28 \%$. Moreover, by comparison with the untreated pyrrhotite, the relative contents of $\mathrm{FeOOH}$ and $\mathrm{Fe}_{2} \mathrm{O}_{3}$ on pyrrhotite surfaces that are treated with conditioning under the natural atmosphere increase up to $31.20 \%$ and $24.43 \%$, respectively. This may indicate that the content of $\mathrm{Fe}^{3+}$ on the surface of pyrrhotite increases, perhaps due to the oxidation of $\mathrm{Fe}^{2+}$ when in contact with oxygen [26]. However, when the pyrrhotite is treated with conditioning under the nitrogen atmosphere for $20 \mathrm{~min}$, the Fe species and their relative contents are similar to that of untreated pyrrhotite.
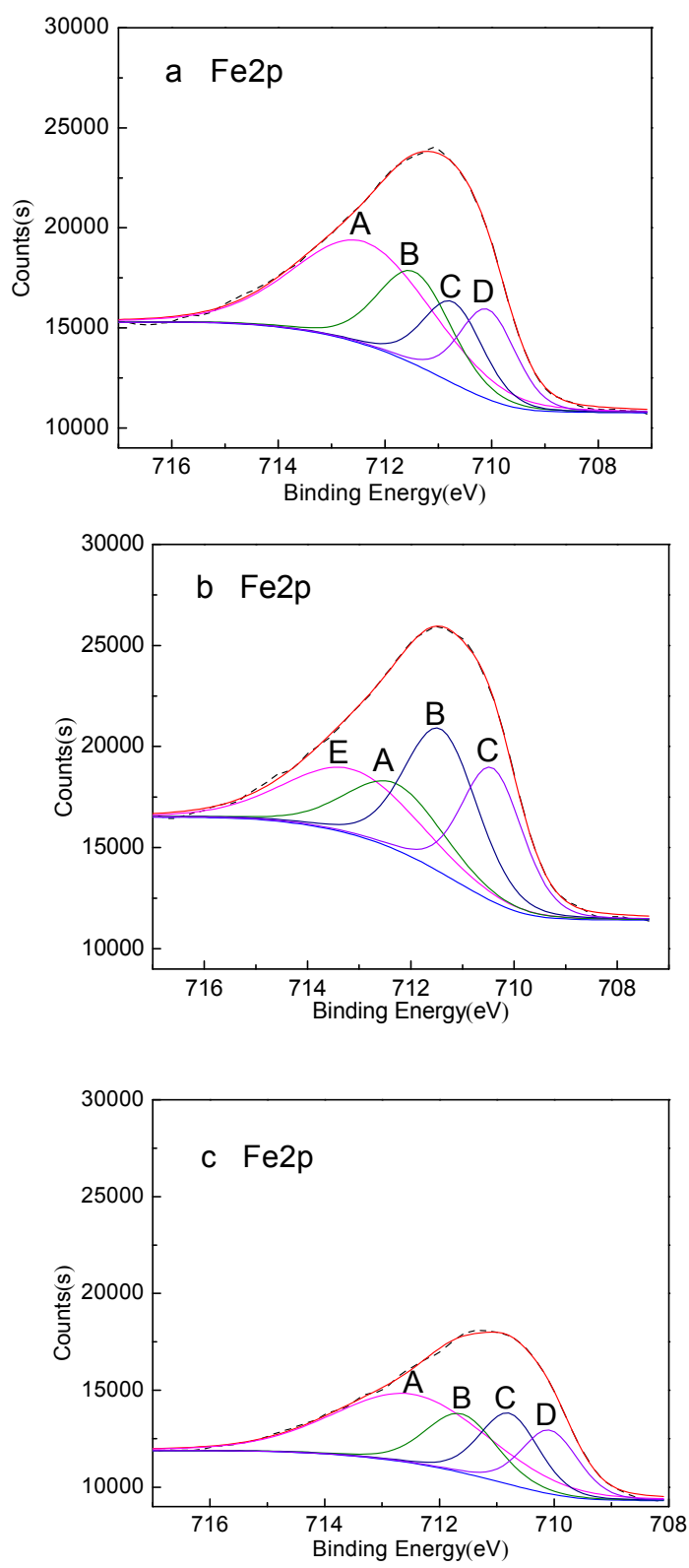

Figure 10. Fe2p spectra for the pyrrhotite surface treated: (a) without conditioning; (b) with conditioning under the natural atmosphere for $20 \mathrm{~min}$; and (c) with conditioning under the nitrogen atmosphere for $20 \mathrm{~min}$. 
Table 2. Fe species binding energy (eV) and relative contents (\%) for the pyrrhotite surface treated with different types of conditioning.

\begin{tabular}{cccccccc}
\hline & & \multicolumn{2}{c}{ Without Conditioning } & \multicolumn{2}{c}{$\begin{array}{c}\text { Conditioning under Natural } \\
\text { Atmosphere for 20 min }\end{array}$} & \multicolumn{2}{c}{$\begin{array}{c}\text { Conditioning under Nitrogen } \\
\text { Atmosphere for 20 min }\end{array}$} \\
\cline { 3 - 8 } Peak & Fe Species & $\begin{array}{c}\text { Binding } \\
\text { Energy (eV) }\end{array}$ & $\begin{array}{c}\text { Relative } \\
\text { Contents (\%) }\end{array}$ & $\begin{array}{c}\text { Binding } \\
\text { Energy (eV) }\end{array}$ & $\begin{array}{c}\text { Relative } \\
\text { Contents (\%) }\end{array}$ & $\begin{array}{c}\text { Binding } \\
\text { Energy (eV) }\end{array}$ & $\begin{array}{c}\text { Relative } \\
\text { Contents (\%) }\end{array}$ \\
\hline $\mathrm{A}$ & $\mathrm{Fe}_{2}\left(\mathrm{~S}_{\mathbf{x}}\right)_{3}$ & 712.40 & 45.83 & 712.30 & 19.09 & 712.48 & 47.05 \\
$\mathrm{~B}$ & $\mathrm{FeOOH}_{\mathrm{CO}}$ & 711.45 & 21.95 & 711.41 & 31.20 & 711.62 & 18.37 \\
$\mathrm{C}$ & $\mathrm{Fe}_{2} \mathrm{O}_{3}$ & 710.72 & 15.78 & 710.42 & 24.43 & 710.78 & 18.62 \\
$\mathrm{D}$ & $\mathrm{FeS}$ & 710.07 & 16.44 & - & - & 710.07 & 15.96 \\
$\mathrm{E}$ & $\mathrm{Fe}_{2}\left(\mathrm{SO}_{4}\right)_{3}$ & - & - & 713.15 & 25.28 & - & - \\
\hline
\end{tabular}

According to Figure 11, the S2p spectra of pyrrhotite samples not treated with conditioning, treated with conditioning under the natural atmosphere for $20 \mathrm{~min}$, and treated with conditioning under the nitrogen atmosphere for $20 \mathrm{~min}$ are composed of four peaks at (A) $161.30 \mathrm{eV}$, (B) $162.60 \mathrm{eV}$, (C) $163.80 \mathrm{eV}$, and (D) $168.50 \mathrm{eV}$, respectively. By comparing the binding energy values of S2p with those from references, the peaks $\mathrm{A}, \mathrm{B}, \mathrm{C}$, and $\mathrm{D}$ are attributed to $\mathrm{FeS}, \mathrm{Fe}_{2}\left(\mathrm{~S}_{x}\right)_{3}, \mathrm{~S}^{0}$, and $\mathrm{Fe}_{2}\left(\mathrm{SO}_{4}\right)_{3}$, respectively $[24,25,27]$. As seen from Figure 11 and Table 3, the $S$ species of the untreated pyrrhotite surfaces mainly consist of $\mathrm{FeS}, \mathrm{Fe}_{2}\left(\mathrm{~S}_{x}\right)_{3}$, and $\mathrm{S}^{0}$, with the relative contents of these being about $33 \%$. For the surfaces of the pyrrhotite treated with conditioning under the natural atmosphere for $20 \mathrm{~min}$, the new species $\mathrm{Fe}_{2}\left(\mathrm{SO}_{4}\right)_{3}$ occurs at a relevant content of $15.38 \%$, which is likely due to the oxidation of the pyrrhotite. However, when the pyrrhotite is conditioned under the nitrogen atmosphere for $20 \mathrm{~min}$, the Fe species and their relevant contents are similar to that of untreated pyrrhotite.
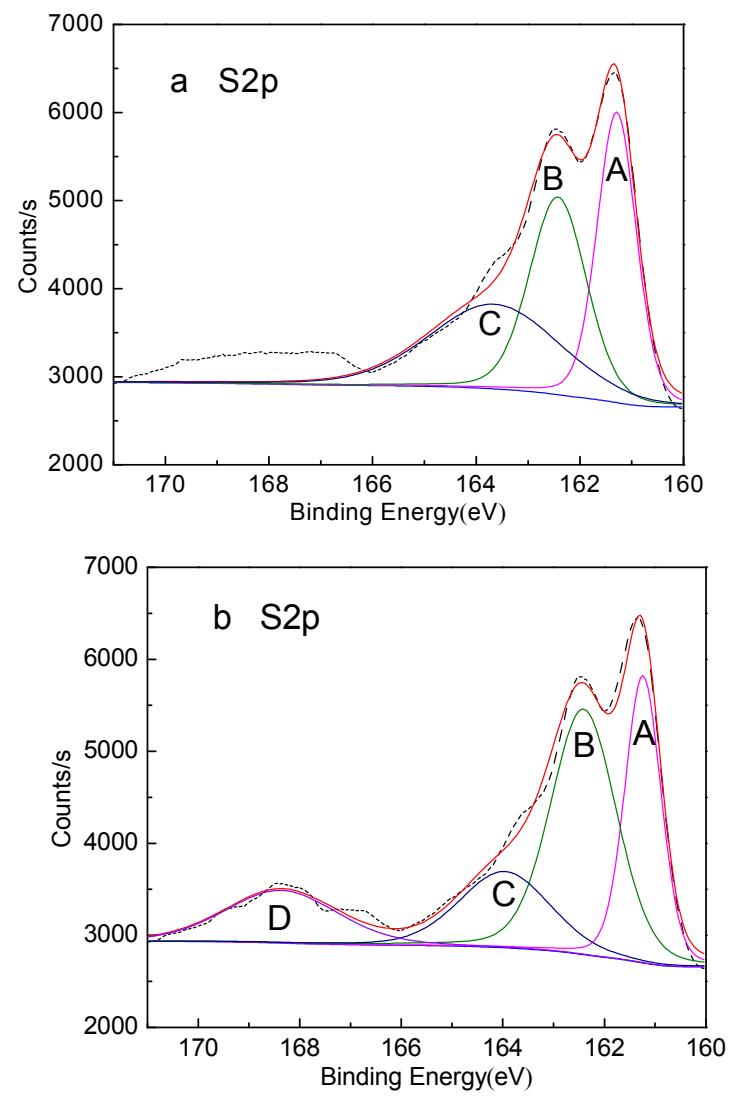

Figure 11. Cont. 


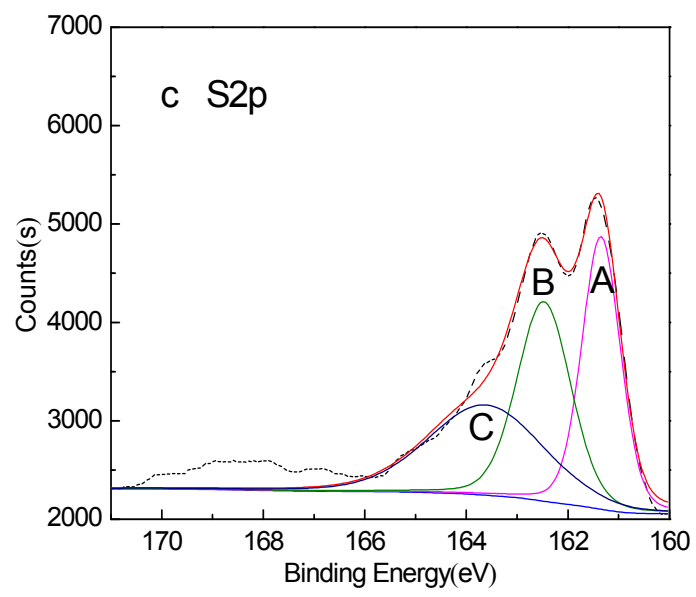

Figure 11. S2p spectra for the pyrrhotite surface treated: (a) without conditioning; (b) with conditioning under the natural atmosphere for $20 \mathrm{~min}$; and (c) with conditioning under the nitrogen atmosphere for $20 \mathrm{~min}$.

Table 3. S species binding energy $(\mathrm{eV})$ and relative contents (\%) for the pyrrhotite surface treated with different types of conditioning.

\begin{tabular}{cccccccc}
\hline & & \multicolumn{2}{c}{ Without Conditioning } & \multicolumn{2}{c}{$\begin{array}{c}\text { Conditioning under Natural } \\
\text { Atmosphere for 20min }\end{array}$} & \multicolumn{2}{c}{$\begin{array}{c}\text { Conditioning under Nitrogen } \\
\text { Atmosphere for 20min }\end{array}$} \\
\cline { 3 - 8 } Peak & S Species & $\begin{array}{c}\text { Binding } \\
\text { Energy (eV) }\end{array}$ & $\begin{array}{c}\text { Relative } \\
\text { Contents (\%) }\end{array}$ & $\begin{array}{c}\text { Binding } \\
\text { Energy (eV) }\end{array}$ & $\begin{array}{c}\text { Relative } \\
\text { Contents (\%) }\end{array}$ & $\begin{array}{c}\text { Binding } \\
\text { Energy (eV) }\end{array}$ & $\begin{array}{c}\text { Relative } \\
\text { Contents (\%) }\end{array}$ \\
\hline $\mathrm{A}$ & $\mathrm{FeS}$ & 161.29 & 33.80 & 161.24 & 27.15 & 161.35 & 33.30 \\
$\mathrm{~B}$ & $\mathrm{Fe}_{2}\left(\mathrm{~S}_{\mathrm{x}}\right)_{3}$ & 162.42 & 33.44 & 162.41 & 33.49 & 162.47 & 33.92 \\
$\mathrm{C}$ & $\mathrm{S}^{0}$ & 163.65 & 32.76 & 163.96 & 20.98 & 163.62 & 32.78 \\
$\mathrm{D}$ & $\mathrm{Fe}_{2}\left(\mathrm{SO}_{4}\right)_{3}$ & - & - & 168.36 & 15.38 & - & - \\
\hline
\end{tabular}

Pyrrhotite is a reactive sulfide mineral and is highly prone to oxidation [6,22]. The extent of oxidation affects the flotation performance of pyrrhotite. Oxidation of the pyrrhotite may occur during all stages in the process involving conditioning [28]. The general oxidation mechanisms can be described as

$$
\begin{gathered}
\mathrm{Fe}_{1-x} \mathrm{~S}+(2-(1 / 2) x) \mathrm{O}_{2}+x \mathrm{H}_{2} \mathrm{O} \rightarrow(1-x) \mathrm{Fe}^{2+}+\mathrm{SO}_{4}^{2-}+2 x \mathrm{H}^{+} \\
\mathrm{Fe}^{2+}+1 / 4 \mathrm{O}_{2}+\mathrm{H}^{+} \rightarrow \mathrm{Fe}^{3+}+1 / 2 \mathrm{H}_{2} \mathrm{O}
\end{gathered}
$$

It is generally believed that the main oxidant agent in pyrrhotite slurry is the dissolved oxygen from atmosphere. Thus, the concentration of dissolved oxygen will influence the rate of pyrrhotite oxidation $[18,20,21,29]$. A faster conditioning speed and longer conditioning time increase the amount of dissolved oxygen in the pulp and thus accelerate pyrrhotite oxidization. Therefore, the hydrophilic iron hydroxides formed through pyrrhotite oxidization coat the surface of pyrrhotite, reducing the adsorption of xanthate onto pyrrhotite surfaces. As a result, the flotation recovery of pyrrhotite is decreased.

\section{Conclusions}

The current study systematically investigated the influence of conditioning on the pyrrhotite flotation performance in the presence of chlorite under different air conditions, which explained the interaction mechanisms of conditioning and provided a reference for further study. Based on the results of this investigation, the following conclusions can be drawn:

1. In pyrrhotite flotation, chlorite slimes impair pyrrhotite flotation performance due to the surface coating. 
2. Conditioning can effectively detach chlorite slimes from pyrrhotite surfaces, resulting in enhanced flotation recovery of pyrrhotite. When mixed minerals were conditioned under the natural atmosphere, a faster conditioning speed and longer conditioning time decreased pyrrhotite flotation recovery to some degree. However, when mixed minerals were conditioned under a nitrogen atmosphere, a faster conditioning speed and longer conditioning time gave better flotation results.

3. XPS analysis shows that when mixed minerals were conditioned under the natural atmosphere, a faster conditioning speed and longer conditioning time accelerates the pyrrhotite surface oxidization, which results in a decrease in pyrrhotite flotation recovery.

4. The industrial tests of nickel sulfide ores under nitrogen atmosphere have not been performed, which will be the focus of the following study.

Acknowledgments: The authors acknowledge the support of the National Basic Research Program of China (2014CB643402), State Key Laboratory of Nickel and Cobalt Resources Comprehensive Utilization and Central South University (2016zzts472).

Author Contributions: Qing Shi conceived and designed the experiments; Yanfei Chen performed the experiments; Qing Shi and Yanfei Chen analyzed the data; Qingming Feng, Yiping Lu and Qing Shi contributed reagents/materials/analysis tools; Yanfei Chen, Qing Shi, Qiming Feng, Yiping Lu and Wencai Zhang wrote and revised the paper.

Conflicts of Interest: The authors declare no conflict of interest.

\section{References}

1. Fornasiero, D.; Ralston, J. Cu(II) and Ni(II) activation in the flotation of quartz, lizardite and chlorite. Int. J. Miner. Process. 2005, 76, 75-81. [CrossRef]

2. Peng, Y.; Bradshaw, D. Mechanisms for the improved flotation of ultrafine pentlandite and its separation from lizardite in saline water. Miner. Eng. 2012, 36-38, 284-290. [CrossRef]

3. Feng, B.; Feng, Q.; Lu, Y. The effect of lizardite surface characteristics on pyrite flotation. Appl. Surf. Sci. 2012, 259, 153-158. [CrossRef]

4. Trahar, W.J. A rational interpretation of the role of particle size in flotation. Int. J. Miner. Process. 1981, 8 , 289-327. [CrossRef]

5. Senior, G.D.; Trahar, W.J. The influence of metal hydroxides and collector on the flotation of chalcopyrite. Int. J. Miner. Process. 1991, 33, 321-341. [CrossRef]

6. Belzile, N.; Chen, Y.; Cai, M.; Li, Y. A review on pyrrhotite oxidation. J. Geochem. Explor. 2004, 84, 65-76. [CrossRef]

7. Allison, S.A.; O'Connor, C.T. An investigation into the flotation behaviour of pyrrhotite. Int. J. Miner. Process. 2011, 98, 202-207. [CrossRef]

8. Engel, M.D.; Middlebrook, P.D.; Jameson, G.J. Advances in the study of high intensity conditioning as a means of improving mineral flotation performance. Miner. Eng. 1997, 10, 55-68. [CrossRef]

9. Chen, G.; Grano, S.; Sobieraj, S.; Ralston, J. The effect of high intensity conditioning on the flotation of a nickel ore. Part 1: Size-by-size analysis. Miner. Eng. 1999, 12, 1185-1200. [CrossRef]

10. Chen, G.; Grano, S.; Sobieraj, S.; Ralston, J. The effect of high intensity conditioning on the flotation of a nickel ore, part 2: Mechanisms. Miner. Eng. 1999, 12, 1359-1373. [CrossRef]

11. Zhang, W.; Honaker, R. Studies on carbon flotation from fly ash. Fuel Process. Technol. 2015, 139, $236-241$. [CrossRef]

12. Bulatovic, S.M.; Salter, R.S. High-intensity conditioning-A new approach to improving flotation of mineral slimes. In Proceedings of the Complex Ores. Mineral Processing and Extractive Metallurgy, Halifax, NS, Canada, 20-24 August 1989.

13. Bulatovic, S.M.; Wyslouzil, D.M. Research and development in selective froth flotation of mineral fines from polymetallic refractory sulfide ores. In Proceedings of the Second International Conference on Mineral Processing and Extractive Metallurgy, Beijing, China, 23-27 July 1992.

14. Feng, B.; Feng, Q.; Lu, Y.; Lv, P. The effect of conditioning methods and chain length of xanthate on the flotation of a nickel ore. Miner. Eng. 2012, 39, 48-50. [CrossRef] 
15. Feng, B.; Feng, Q.; Lu, Y. Mechanism of hetero-aggregation of chlorite and pyrite. J. Cent. South Univ. 2015, 46, 14-19.

16. Tsai, C.; Pui, D.Y.H.; Liu, B.Y.H. Particle detachment from disk surfaces of computer disk drives. J. Aerosol Sci. 1991, 22, 737-746. [CrossRef]

17. Phares, D.J.; Smedley, G.T.; Flagan, R.C. Effect of particle size and material properties on aerodynamic resuspension from surfaces. J. Aerosol Sci. 2000, 31, 1335-1353. [CrossRef]

18. Chinchón-Payá, S.; Aguado, A.; Chinchón, S. A comparative investigation of the degradation of pyrite and pyrrhotite under simulated laboratory conditions. Eng. Geol. 2012, 127, 75-80. [CrossRef]

19. Becker, M.; Villiers, J.D.; Bradshaw, D. The flotation of magnetic and non-magnetic pyrrhotite from selected nickel ore deposits. Miner. Eng. 2010, 23, 1045-1052. [CrossRef]

20. Chiriţă, P.; Descostes, M.; Schlegel, M.L. Oxidation of FeS by oxygen-bearing acidic solutions. J. Colloid Interface Sci. 2008, 321, 84-95. [CrossRef] [PubMed]

21. Janzen, M.P.; Nicholson, R.V.; Scharer, J.M. Pyrrhotite reaction kinetics: Reaction rates for oxidation by oxygen, ferric iron, and for nonoxidative dissolution. Geochim. Cosmochim. Acta 2000, 64, 1511-1522. [CrossRef]

22. Miller, J.D.; Li, J.; Davidtz, J.C.; Vos, F. A review of pyrrhotite flotation chemistry in the processing of PGM ores. Miner. Eng. 2005, 18, 855-865. [CrossRef]

23. Nesbitt, H.W.; Muir, I.J. X-ray photoelectron spectroscopic study of a pristine pyrite surface reacted with water vapour and air. Geochim. Cosmochim. Acta 1994, 58, 4667-4679. [CrossRef]

24. Brion, D. Etude par spectroscopie de photoelectrons de la degradation superficielle de FeS2, CuFeS2, ZnS et PbS a l'air et dans l'eau. Appl. Surf. Sci. 1980, 5, 133-152. [CrossRef]

25. Dzhurinskii, B.F.; Gati, D.; Sergushin, N.P. An X-ray photoelectron spectroscopic study of certain oxides. Russ. J. Inorg. Chem. 1975, 20, 2307-2314.

26. Liu, X.; Huang, G.; Li, C.; Cheng, R. Depressive effect of oxalic acid on titanaugite during ilmenite flotation. Miner. Eng. 2015, 79, 62-67. [CrossRef]

27. Barr, T.L. An ESCA study of the termination of the passivation of elemental metals. Chemischer Informationsdienst. 1978, 9, 1801-1810. [CrossRef]

28. Bunkholt, I.; Kleiv, R.A. Pyrrhotite oxidation and its influence on alkaline amine flotation. Miner. Eng. 2015, 71, 65-72. [CrossRef]

29. Ekmekçi, Z.; Becker, M.; Tekes, E.B.; Bradshaw, D. The relationship between the electrochemical, mineralogical and flotation characteristics of pyrrhotite samples from different Ni Ores. J. Electroanal. Chem. 2010, 647, 133-143. [CrossRef] 